\title{
Counsel and Covenant: Aristocratic Conciliarism and the Scottish Revolution
}

\section{ROGER A. MASON}

The political thought of the Covenanting Revolution in Scotland is almost invariably studied from the perspective of the theories of resistance to tyranny articulated by clerics such as Alexander Henderson and Samuel Rutherford. ${ }^{1}$ Only rarely do historians look beyond these essentially religious justifications of rebellion and explore the ideological resources of a secular nature drawn on and deployed by those without whose support the Covenanting movement would never have got off the ground - the landed elite in general and the titled nobility in particular. $^{2}$ This chapter seeks to recover the ways in which the nobility might have viewed their relationship with the king, and how, when and with what ideological consequences that

\footnotetext{
${ }^{1}$ For an overview with bibliographical references, see G. Burgess, British Political Thought, 1500-1640 (Houndsmill, Palgrave MacMillan, 2009), pp. 188-93.

${ }^{2}$ Though see K. M. Brown, Noble Power in Scotland from the Reformation to the Revolution (Edinburgh, Edinburgh University Press, 2011), pp. 3-10 and passim, which broaches some of the issues explored below. P. Donald, An Uncounselled King: Charles I and the Scottish Troubles, 1637-1641 (Cambridge, Cambridge University Press, 1990), treats the practice of counsel in detail, but without reflecting on its ideological significance.
} 
relationship was fractured.

A key part of the discussion is an analysis of the historical writings of Sir James Balfour of Denmilne (c.1600-57), who in 1630 was appointed Charles I's senior heraldic officer in Scotland (Lord Lyon King at Arms), and whose works provide fascinating insights into a form of aristocratic conciliarism that was, arguably, at the heart of contemporary Scottish political culture. For Balfour, the outbreak of the Covenanting Revolution was the result of a breakdown of conciliar politics that had seen the king's natural born counsellors displaced by an upstart clerisy. A similar set of underlying assumptions about the nature of the relationship between the crown and the aristocracy can be found in the writings of both David Hume of Godscroft (1558c.1630), whose History of the Houses of Douglas and Angus was posthumously published in 1644, and in the works of William Drummond of Hawthornden (1585-1649), whose History of the Five Jameses also appeared posthumously in 1655 . However, while their diagnoses of political breakdown were cut from the same ideological cloth, their remedies differed markedly: while Hume advocated aristocratic resistance to tyranny, Drummond excoriated it. Balfour, it is argued here, represents something of a middle ground, albeit closer to Hume than Drummond, and might well be taken as reflecting the views of the Scottish landed elite more generally. Profoundly disillusioned by Charles I's governance of Scotland, he supported the National Covenant of 1638, but by 1641 found the constitutional radicalism of the movement's leadership equally distasteful and was increasingly aghast at the radical forces that the movement had unleashed. Before exploring Balfour's views more fully, however, it is worth establishing what common ground he shared with Hume and Drummond. For together their works illuminate how the discourse of counsel offered, on the one hand, a reassuring picture of the interdependence of crown and nobility, but on the other, a much more ambivalent attitude to the issue of resisting a 
king who ignored the counsel he was offered.

\section{I}

Hume's History of the Houses of Douglas and Angus, though perhaps begun as early as 1595 and completed before the death of James VI in 1625, was not published in full until 1644 (and then in an edited version that Anglicised the original Scots vernacular). ${ }^{3}$ It is only recently, and largely through the work of Arthur Williamson, that Hume himself has emerged as one of the leading intellectuals of the Jacobean era. ${ }^{4}$ His little-known discourses on Anglo-Scottish union, for

${ }^{3}$ It was Hume's daughter, Anna Hume, who was responsible for seeing the work through the Edinburgh press of Evan Tyler in 1644 in a version that thoroughly Englished Godscroft's original Scots vernacular. Tyler re-issued the book in 1648 under two variant titles: A Generall History of Scotland, Together with a Particular History of the Houses of Douglas and Angus, and (for the London market) The History of the Houses of Douglas and Angus Wherein are Discovered the Most Memorable Passages of the Kingdom of Scotland from the Yeer 767, to the Reign of our Late Soveraign Lord King James the Sixth. An earlier edition of the first part of the text - The Lyues of the Illustrious Familie and Name of Douglas - was published in Edinburgh in $c .1634$. For a modern critical edition, see David Hume of Godscroft's The History of the House of Douglas, ed. D. Reid, 2 vols (Edinburgh, Scottish Text Society, 4th ser., 25-6, 1996), and David Hume of Godscroft's The History of the House of Angus, ed. D. Reid, 2 vols (Edinburgh, Scottish Text Society, 5th ser., 4-5, 2005). All references here are to the edition of 1644.

${ }^{4}$ For biographical details, see A. H. Williamson and P. J. McGinnis, 'Hume, David, of Godscroft 
example, De Unione Insulae Britannicae, are perhaps the most original and visionary of the treatises prompted by the accession of James VI to the English throne in 1603, and display both Hume's commitment to a Presbyterian ecclesiastical polity and his deep engagement with civic humanism. ${ }^{5}$ In these respects his work strongly resonates with George Buchanan's, and his History is grounded in the same political philosophy that informs Buchanan's Rerum Scoticarum Historia of 1582. Central to Buchanan's understanding of the Scottish past was not only a belief in the historical legitimacy of elective monarchy, but also a powerful restatement of the critical role that the aristocracy had traditionally performed in defending the commonweal of the realm. In contrast to the radical populism of his De Iure Regni apud Scotos (1579), Buchanan's Historia was socially more conservative, adopting and adapting a conventional understanding of the nobility's role as the monarch's born counsellors and giving it a distinctly radical edge. Just as the nobility were duty bound to advise their monarchs, so they were also obliged to resist, restrain, depose and even execute them should their behaviour threaten the public good. ${ }^{6} \mathrm{~A}$ (1558-1629x31)', ODNB [accessed 16 June 2014]. Some of the themes developed here are broached in D. Reid, 'Hume of Godscroft on Kings and Subjects', in S. Mapstone (ed.), Older Scots Literature (Edinburgh, John Donald, 2005).

${ }^{5}$ A. H. Williamson and P. J. McGinnis (eds), The British Union: A Critical Edition and Translation of David Hume of Godscroft's 'De Unione Insulae Britannicae' (Aldershot, Ashgate, 2002).

${ }^{6}$ On these themes, see the introduction to George Buchanan, A Dialogue on the Law of Kingship Among the Scots, a Critical Edition and Translation of George Buchanan's 'De Iure Regni apud Scotos Dialogus', ed. M. S. Smith and R. A. Mason (Aldershot, Ashgate, 2004), and R. A. Mason, 'Beyond the Declaration of Arbroath: Kingship, Counsel and Consent in Late Medieval 
notable aspect of Buchanan's aristocratic conciliarism, and one that was shared by Hume, was a lack of concern for the institutional framework through which counsel was offered and received. In a manner that was not uncommon in humanist political discourse, both men saw the Scottish polity as operating on the basis of a moral economy of vice and virtue derived from classical republican sources rather than constitutional conventions rooted in legal precepts. ${ }^{7}$

However, while they had much in common, in one respect their histories differed markedly. For whereas Buchanan portrayed the earls of Douglas and Angus in largely negative terms, as over-mighty feudal barons, Hume was writing a family history that memorialised them as 'patriots' imbued with an overriding sense of responsibility to the commonweal. ${ }^{8}$ This view was shaped by his close association with Archibald Douglas, eighth earl of Angus (c.1555-88), whose death in his early thirties was much lamented by the Presbyterian clergy and their lay sympathisers. ${ }^{9}$ The nephew of James Douglas, fourth earl of Morton, who had acted as regent for James VI until his overthrow in 1578 and execution in 1581, Angus was deeply engaged in the and Early Modern Scotland', in S. Boardman and J. Goodare (eds), Kings, Lords and Men in Scotland and Britain, 1300-1625 (Edinburgh, Edinburgh University Press, 2014).

${ }^{7}$ On this more generally, see M. Peltonen, Classical Humanism and Republicanism in English Political Thought, 1570-1640 (Cambridge, Cambridge University Press, 1995).

${ }^{8}$ Hume was among the first to use the term 'patriot', a neologism of the 1570s; on its wider significance, see A. Williamson, 'George Buchanan and the Patriot Cause', in C. Erskine and R. A. Mason (eds), George Buchanan: Political Thought in Early Modern Britain and Europe (Aldershot, Ashgate, 2012).

${ }^{9}$ G. R. Hewitt, 'Douglas, Archibald, 8th earl of Angus and 5th earl of Morton (c.1555-88)', ODNB [accessed 16 June 2014]. 
complex political and religious struggles that marked James VI's emergence from adolescence, suffering periods of exile in England for his pains. Although not directly implicated in the Ruthven Raid of 1582, Angus was closely aligned with the disaffected nobles who held the king captive for over a year before being forced into exile along with the staunchly Presbyterian clerics who had supported them. Hume was intimately involved in these events, acting as Angus's secretary and confidant, and his History of the Houses of Douglas and Angus ends with a revealing dialogue between the two of them about the legitimacy of restraining and resisting a king - a dialogue to which we must return.

Meanwhile, what of the scope and character of the History as a whole? Its first part is organised in terms of the careers of successive lords of Douglas, up to and including the 'good' Sir James Douglas, Robert Bruce's right-hand man in the early-fourteenth-century wars with England, and on to the fifteenth-century earls of Douglas who were eventually - and, in Hume's telling, unfairly - destroyed by the rising authoritarianism of the royal Stewart dynasty. The second part then traces in similar manner the fortunes of the Douglas earls of Angus, including Archibald the fifth earl ('Bell-the-Cat'), who played a key role in the rebellions against James III in 1482 and 1488, and his grandson and successor, Archibald the sixth earl, whose marriage to James IV's widow Margaret Tudor in 1514 marked the beginning of a lengthy career in AngloScottish politics. By far the longest part of the History, however, is devoted to the postReformation era and the career of Hume's patron and friend, Archibald, the eighth earl, and the latter's 'Uncle and Tutour', James Douglas, fourth earl of Morton. ${ }^{10}$ From beginning to end, over 400 closely printed pages, Hume holds up the earls of Douglas and Angus as paragons of

\footnotetext{
${ }^{10}$ Hume in fact describes him as the ninth earl of Angus, but this numbering is based on the erroneous attribution of the Angus earldom to William, first earl of Douglas (1342-84).
} 
aristocratic virtue, devoted to the commonweal even at the expense of their own and their family's private advantage. It is a vision of Scottish political culture that, in the same way as Buchanan's, limits the bounds of royal authority just as it legitimises the political agency of the nobility. As Hume put it in the preface to the History, not even the famed Roman republican families the Fabii and Cornelii 'doth equal' the Douglases. ${ }^{11}$ Like those of their classical counterparts, their careers offered examples of enlightened patriotism that commanded respect and emulation.

If this suggests Hume's profound indebtedness to republican thinking, he did not entirely efface monarchical power. Rather, a key theme that resonates throughout the History - as it does in northern European humanist thinking more generally - is the role of the nobility as the king's natural born counsellors. Moreover, just as it was the unalterable birthright of the nobility to counsel and admonish the prince, so it was the prince's bounden duty to consult with the nobility and act on their advice. A fine example of this is provided by Hume's account of the proposal for a dynastic union with England that David II laid before the Scottish Estates in 1363. According to Hume, the nobility acted in the best interests of the kingdom in unanimously rejecting the plan and, while this initially angered the king, the proposal was soon dropped and David reconciled with those who had opposed his will. This prompts Hume to describe the episode as:

A notable example to Counsellors, of freedome, where the Princes good, and the good of their Countrey doth require it: to Princes of modestie in opposition made to that which may be their will for a time, and whereunto for the present appearance they may be very

\footnotetext{
${ }^{11}$ Hume, History, sig. B1r-v; a point also made by McGinnis and Williamson, 'Hume, David, of Godscroft'.
} 
bent. A happy King that can so dispose himself not to be wedded to his own affection onely! Or if not so, yet happy is hee that hath such Counsellers, who will resolutely remonstrate their right, and stand to it, by which means he may be brought to examine his own affections, to see the errours of them, and rejoice thereafter that he did not what he most desired. ${ }^{12}$

As noted above, just as Hume's aristocratic conciliarism echoes that of Buchanan, so he shows a similar lack of interest in the institutional framework through which the nobility might 'resolutely remonstrate their right'. The Three Estates or Parliament do not figure significantly as the constitutional bodies through which protest can be channelled and there is no explicit legal framework governing the actions of crown and community. It is for Hume a matter of mutual trust and a willingness on the part of the crown to accept as 'a chiefe, yea almost the onely point of true policy, to love and make much of all men, and most specially their Nobilitie'. It follows that, in Hume's view, those who seek to diminish the power of the nobility, and to lessen their authority over their dependants, 'erre greatly in policie, and unadvisedlie cut the props of the prince's standing, which being brangled [shaken] but a little, his kingdom is easily bereft him, all authoritie going away with his owne person'. ${ }^{13}$

The other side of this coin, with which Hume is obsessively concerned, is the pernicious influence of low-born favourites, upstarts who monopolise the ear of the king and who 'goe

\footnotetext{
${ }^{12}$ Hume, History, p. 85.

${ }^{13}$ Hume, History, pp. 73-4. Hume's use of the term 'policy' might imply some familiarity with contemporary notions of 'reason of state'. However, this is not borne out by the straightforwardly humanist vocabulary of counsel prevalent in the History as a whole.
} 
commonly about to perswade Princes, that ancient Noblemen are enemies to them, and barres to their absolutenesse' ${ }^{14}$ It is from this perspective that Hume seeks to interpret the souring of relations between the Douglases and the Stewart monarchy in the reigns of James I and especially James II. Thus he laments the rise, following the assassination of James I in 1437, of lesser landowners such as Alexander Livingstone and William Crichton, 'small Barons onely, and not of the ancient blood of the Nobilitie; new men bent to seek their owne profite onely, without regard to any other duty'. ${ }^{15}$ It was men such as these, motivated solely by private advantage, and without a thought for the public good, who encouraged the Stewart kings to tyrannise over their subjects. However, by far the best example of this - not least on account of the key role played by the fifth earl of Angus - was the rebellion against James III in 1482 and the hanging of his favourites, 'base men both in place and worth, whom he had advanced to honours, and nobilitated'. ${ }^{16}$ For Hume this was not simply a necessary purging of evil counsel, but one which was accomplished with due respect for the king himself, who suffered no harm. It was, in short:

A very remarkable and rare example of carefulnesse of the Common-wealth, joined with all modestie, love, and dutifulnesse toward their king. Their behaviour was just such as Lawyers prescribe in such cases, who accounting the person of the Prince sacred, and not to be touched any way, do allow that their wicked counsellors and abusers only be taken order with, where the good

\footnotetext{
${ }^{14}$ Hume, History, p. 155.

${ }^{15}$ Hume, History, pp. 140-1; cf. pp. 154-5.

${ }^{16}$ Hume, History, p. 222.
} 
of the Countrey enforceth it. ${ }^{17}$

In this instance, however, the execution of the king's upstart counsellors did little to change the king himself, who rapidly slipped back into his vicious ways. Consequently, the nobility, fearing for the commonwealth, were now forced into a position where there was no alternative to armed resistance to the king. 'Yet,' says Hume, 'can they not be alienated from the race of their Kings. His son had not offended, and fell to succeed. They affect him for their captain'. The two sides muster their forces; James is defeated at Sauchieburn in 1488; and (despite the best efforts of Angus to prevent it) is slain while in hiding after the battle. Hume concludes the episode by once again praising the moderation of the nobility and by approving wholeheartedly of their virtuous efforts to preserve the commonwealth. ${ }^{18}$

This example of 'carefulness of the commonwealth' provides Hume with an ideal precedent for the actions of the Ruthven Raiders, who seized and imprisoned the young James VI in 1582, ousting his favourite, Esmé Stuart, duke of Lennox. Hume’s patron, the eighth earl of Angus, was not personally involved in the Ruthven Raid - he had been forced into English exile when his uncle, the Regent Morton, was executed in 1581 - but he was closely aligned with the leader of the coup, William Ruthven, earl of Gowrie, with whom he subsequently colluded in the complex political manoeuvrings that led in 1585 to the final overthrow of James Stewart, earl of Arran, who had taken Lennox's place as the king's favoured courtier. In Hume's telling, Arran's 'tyranny' posed a grave threat to both kingdom and kirk, and the actions of the nobility - 'Peeres of the Land, and Privie Counsellors by Birth' - in freeing James of his 'wicked Counsellors' was

\footnotetext{
${ }^{17}$ Hume, History, pp. 226-7.

${ }^{18}$ Hume, History, pp. 229-32. For one fifteenth-century response to these events, see Claire Hawes's essay in this volume.
} 
the only course open to those who truly had to heart the interests of king and commonwealth. ${ }^{19}$

It was immediately following his account of these events that Hume gave his version of a lengthy conversation with Angus designed to assuage the latter's tender conscience at having resisted the authority of his anointed sovereign. The discussion is prompted by a sermon on the duty of obedience that, in Hume's view, had failed to distinguish between lawful kings and the unlawful commands of tyrants. ${ }^{20}$ Interestingly, in pursuing this argument, Hume chose to question Jean Bodin's view that unstinting obedience must be extended even to tyrants because their sovereignty is absolute and, by definition, 'their subjects have no jurisdiction over them'. For Hume, it was quite illogical for Bodin to argue (as he did) that, while a foreign monarch might be invited to intervene to restrain a tyrant, the people themselves had no right to resist him. ${ }^{21}$ However, although the thrust of his argument suggests that Hume adhered to a form of 'popular' sovereignty such as Buchanan had set out, he does not elaborate on such views. Rather, he argues that, just as Bodin admits that men may degenerate into wolves and kings into tyrants,

${ }^{19}$ Hume, History, pp. 383-4; cf. pp. 403-4.

${ }^{20}$ Hume, History, pp. 414-29. It is unlikely that Hume's is a verbatim record of the conversation - invented speeches and dialogue are characteristic of humanist historical writing - but it is perfectly possible that some such discussion took place, and Hume's tacit admission that he failed to persuade his patron may be indicative of this.

${ }^{21}$ Hume, History, p. 418. Hume refers to De Republica, the Latin version published in 1586 of Bodin's Six Livres de la République, first published in 1576. Bodin included Scotland among those absolute monarchies where sovereignty was vested exclusively in the crown and where therefore 'the subject has no right of jurisdiction over his prince'. See Jean Bodin, On Sovereignty, ed. J. H. Franklin (Cambridge, Cambridge University Press, 1992), p. 115. 
so it follows - he poses the conclusion as a rhetorical question - that a wolfish tyrant must surely be 'worthie to bee deprived of that Kingdome, which he cannot, or will not guide rightly, but destroyes and makes havock of all?'22 Finally, Hume turns to Adam Blackwood, the Gallicised Scot who had written a refutation of Buchanan's De Iure Regni, published in Poitiers in 1581, in which he had conceded that, while it is unlawful to resist a king, it is permissible to remove a king's evil counsellors. To this Hume responds bluntly, and in terms that serve to radicalise his account of the hanging of James III's favourites in 1482, that Blackwood's distinction is simply too nice to be tenable. At the very least, as the king appoints his counsellors, to restrain them is to resist him. 'So that,' he concludes, 'if Blackwood say that it is lawfull to punish wicked Counsellors, he must confesse also, that it is lawfull to control Kinges'. Clearly Hume would have no truck with the absolutist ideas of Bodin, Blackwood or, indeed, James VI. ${ }^{23}$ While Angus, as Hume dutifully notes, was equivocal in his response to the case for aristocratic resistance, Hume himself clearly took the view that kings might legitimately be restrained by their leading subjects.

${ }^{22}$ Hume, History, pp. 418-19, citing Bodin's Demonomania (1580) on how a king may become a wolf, though the trope derives from Plato's Republic, 565d-566a. Buchanan refers to the same passage in his On the Law of Kingship, p. 89, in the course of setting out the people's right to hold a tyrant to account.

${ }^{23}$ Hume, History, pp. 419-23, citing Blackwood 'Apol. cap. 34'. On Blackwood's Adversus Georgii Buchanani Dialogum ... Pro Regibus Apologia (Poitiers, 1581), see J. H. Burns, 'George Buchanan and the Monarchomachs', in R. A. Mason (ed.), Scots and Britons: Scottish Political Thought and the Union of 1603 (Cambridge, Cambridge University Press, 1994). 


\section{II}

On its publication in 1644, the poet, polemicist and historian, William Drummond of Hawthornden, was asked by the first marquess of Douglas to comment on Hume's History. Predictably, the royalist Drummond pronounced it 'extream puritanicall': 'This Booke by these tymes will be made much of: and aboue the whole the last part of it, where are discourses which authorize Rebellion, and the forcing of consciences, and putting the sword in the people's hands' ${ }^{24}$ T. I. Rae has explored in some detail Drummond's deeply conservative understanding of royal authority as part of a divinely ordained social order in which the monarch was accountable only to God, obedience was paramount and resistance to the king's will anathema. ${ }^{25}$ As will become clear, this did not mean that the king was above criticism or that the giving and

${ }^{24}$ G. P. Johnston, 'The First Edition of Hume of Godscroft's History', Papers of the Edinburgh Bibliographical Society, 4 (1901), 149-71, esp. 156-7. William Douglas, eleventh earl of Angus (1589-1660), was made marquess of Douglas by Charles I in 1633. A well-travelled scholar rather than a major political player, he was lukewarm about the covenants and sympathetic to the royalist cause.

25 T. I. Rae, 'The Political Attitudes of William Drummond of Hawthornden', in G. W. S. Barrow (ed.), The Scottish Tradition: Essays in Honour of R. G. Cant (Edinburgh, Scottish Academic Press, 1974). More recent scholarship on Drummond, notably J. Kerrigan, Archipelagic English: Literature, History and Politics, 1603-1707 (Oxford, Oxford University Press, 2008), ch. 4: 'Drummond and the British Problem', places his writings in the context of his ambivalent attitude to the union of 1603, but addresses the issues broached here only tangentially. 
receiving of counsel was not a critical element of Drummond's thinking. What it did mean, however, was that he could envisage no means of redress in the event of a king who chose wilfully to ignore the counsel offered to him.

Drummond had played a key role in choreographing the elaborately fulsome pageantry that marked Charles I's return to Scotland in 1633 for his coronation, but his increasing frustration at his monarch's intransigence is all too clear in the manuscript tracts he wrote in the later 1630s as opposition to Charles's regime in Scotland crystallised in the National Covenant of $1638 .^{26}$ These feelings can also be discerned in his History of Scotland, From the Year 1423 until the Year 1542, better known as the History of the Five Jameses and which, though not published until 1655, some years after Drummond's death, was largely written in the crucial period between 1639 and 1644, as Charles I's grip on his three kingdoms was challenged and destroyed. ${ }^{27}$ Not unexpectedly, what emerges from its pages is a picture of Scottish politics that, while not uncritical of the Stewart kings, viewed the nobility in terms very different from those of Hume of Godscroft. While Drummond does obliquely acknowledge their role as the king's natural born counsellors, he does so in the course of describing each of the reigns of the five Jameses in terms that portray the self-serving ambitions of the nobility, not least the houses of

${ }^{26}$ The most famous of these - 'An Apologetical Letter' and 'Irene' (both discussed further below) - are printed along with several others in The Works of William Drummond of Hawthornden (Edinburgh, 1711). On Drummond's authorship of the 1633 pageant, see Kerrigan, Archipelagic English, pp. 153-6.

27 The History comprises the first part of Drummond, Works. For a full and helpful analysis, including details of its composition, see T. I. Rae, 'The Historical Writing of Drummond of Hawthornden', Scottish Historical Review, 54 (1975), 22-62. 
Douglas and Angus, as grave threats to the authority of the crown and the stability of the kingdom.

Unlike Hume, and in contrast to his own polemical writings, Drummond in his History is notably restrained in explicitly articulating his own views. Like Hume, however, he was not above putting lengthy speeches of his own invention into the mouths of historical actors. One such occasion occurs early in the History when, following his return to Scotland in 1424 from his English captivity, James I set about renewing the kingdom's traditional alliance with France. In Drummond's telling, both the French and English ambassadors were given the opportunity to dilate on the advantages of alliance with their respective kingdoms. While Lord Scrope, the English envoy, gave voice to sentiments that echo the unionist rhetoric of James VI and I - 'Are we not a people inhabiting one Island, have we not both one Language, are we not of like Habit and Fashion, of like quality and condition of life, guarded and separated from the other World by the great depths of the Ocean?' - the anonymous French ambassador responded in terms that echo the Scots' fears after 1603 of simple absorption into a greater England. If this reflects Drummond's ambivalence about Scotland's status within the union, it may also indicate uncertainty about the nature of its governance. For he has the French ambassador go on to make a more unexpected claim:

Ye enjoy now a kind of mixed Government (my Lords) not living under Absolute Sovereignty: Your King proceedeth with you more by Prayers and Requests than by Precepts and Commandments, and is rather your Head than Sovereign, as ruling a Nation not conquered. But when ye shall be joined in a Body with that Kingdom which is absolutely Royal and purely Monarchical, 
having long suffered the Laws of a Conquerour, ye shall find a change and a terrible Transformation. ${ }^{28}$

It is impossible to say how much of this reflects Drummond's own views. He may well have shared the belief that England was not a mixed monarchy - what Sir John Fortescue famously called a dominium politicum et regale - but an absolute one in which, as James VI argued in his Trew Lawe of Free Monarchies (1598), the crown possessed complete sovereignty by right of conquest. ${ }^{29}$ As Drummond must have known, James held that the same applied in Scotland. ${ }^{30}$ Yet here it is argued that, precisely because Scotland had never been conquered, it was more akin than England to a mixed monarchy in which the king, rather 'Head than Sovereign', ruled 'more by Prayers and Requests than by Precepts and Commandments'.

Whatever Drummond's precise views, it is hard not to read this passage as reflecting on Charles I's troubled relations with his three kingdoms in general and Scotland in particular. In the same way, Drummond may well have had contemporary events in mind when he had Mary of Gueldres, James III's widowed mother, advise her adolescent son not only to 'make your subjects obey you more out of love than fear' - a conventional humanist trope - but also to remember that he ruled 'not the soft effeminate People of the South, but a fierce and warlike Nation of the North, which oftner use to be intreated than commanded by their Princes'. 'Beware

${ }^{28}$ Drummond, Works, pp. 10-12.

${ }^{29}$ King James VI and I, Political Writings, ed. J. P. Sommerville (Cambridge, Cambridge University Press, 1994), p. 74.

${ }^{30} \mathrm{Cf}$. James VI and I, Political Writings, p. 73, on the first king of Scots, Fergus, who coming out of Ireland, 'made himself King and Lorde, as well of the whole lands, as of the whole inhabitants within the same'. 
of flatterers,' she continues, 'and exalting undeserving Persons above your ancient Nobility'.31 This was of course precisely what James III became notorious for doing, and what Buchanan and Hume had construed as legitimate grounds for restraining and resisting the king. Not surprisingly Drummond takes a rather different view. Whereas Hume characterises the nobility as 'the Props of the Prince's standing', Drummond describes them as 'like the Ivy' that 'began to sap the Wall by which they had been supported'. ${ }^{32}$ Whereas for Hume the nobility's role as the king's natural born counsellors was axiomatic, for Drummond James III's nobility 'pretended to that out of Right, which was only due unto them by Favour'. ${ }^{33}$ Yet, for all that this suggests a clear view of James III's sovereign rights being violated by over-mighty magnates, Drummond's account of James III's reign - surely echoing his views of Charles I's government - is in fact highly ambivalent: one moment sympathising with the grievances of the nobility, the next condemning them as avaricious; one moment upbraiding the king for his foolishness, the next defending his character and achievements. Such ambivalence, however, is also revealing: although forced to concede that James III was an inept ruler, who slighted his ancient nobility and promoted lowborn favourites, and whose actions threatened the stability of the commonwealth, Drummond could not countenance resistance and would not admit that the nobility had any right of redress. It is not clear why Drummond ended his History with the death of James V in 1542 or, consequently, how he might have dealt with the deposition of Mary Queen of Scots in 1567 or even the rebellion of 1559-60 that first established the Protestant religion in Scotland. However, just as he experienced more difficulty in writing about James III than any of the other Stewart

\footnotetext{
${ }^{31}$ Drummond, Works, p. 42.

${ }^{32}$ Drummond, Works, p. 52.

${ }^{33}$ Drummond, Works, p. 56.
} 
kings, ${ }^{34}$ so it is unlikely that he would have been able to square the circle of legitimate resistance to royal tyranny. In 1635, when Lord Balmerino was put on trial for possessing a petition critical of Charles I's religious innovations, Drummond penned 'An Apologetical Letter' in which he subjected the king's governance of Scotland to some trenchant criticism, pointedly suggesting that the time had come for Charles to conciliate his subjects and listen to those who in all sincerity were interested in 'amending Disorders, and bettering the Form of his Government'. Indeed, he argued that 'the Voice of the People should not be kept up from the Ears of a Prince', and even went so far as to advise Charles 'to read Jan Mariana and George Buchanan's Piece de jure Regni Apud Scotos, for his own private and the publick Good' ${ }^{35}$ In 1638 , when he wrote a further pamphlet 'Irene', Charles had belatedly given in to some of the Covenanters' demands, but Drummond was now fearful that chaos - the complete dissolution of political and social order - would ensue. 'Love, Unanimity and Concord', he argued, 'are the Ground-work, the Pillars, the Cement of all Estates and Common-wealths'. Union and concord, however, were founded on 'lawful Command and due Obedience'. In the latter's absence - when, in effect, legitimate criticism of the king spiralled into illegal resistance to him - 'nought should be found but a disorderly License to do Evil. A Confusion of Every Thing, and a total Ruine of the State'.36

${ }^{34}$ Rae, 'Historical Writing of William Drummond', 26, 43.

${ }^{35}$ Drummond, Works, pp. 133-4. Juan de Mariana (1536-1624) was a Spanish Jesuit who had argued the case for legitimate resistance to tyranny in his De Rege et Regis Institutione (Toledo, 1598).

${ }^{36}$ Drummond, Works, p. 165. 


\section{III}

In many respects Hume and Drummond can be seen as representing two poles on the same political spectrum, both endorsing forms of baronial conciliarism, but with their understanding of the powers and functions of the nobility determined by different conceptions of limited and absolute monarchical sovereignty. Their divergent attitudes to the issue of resistance to tyranny is especially revealing, Hume adhering essentially to the views of George Buchanan, with Drummond elaborating on those of James VI. Yet, for the lay elite in Scotland in the years around 1638, there was perhaps a middle way between these two extremes. The Annales of Sir James Balfour offer a rich (but hitherto unexploited) source in which the attitudes of a learned and intelligent layman to the revolutionary events of the Covenanting era can be traced. Balfour was born in 1600 and from an early age displayed an interest in history in general and heraldry in particular that secured him in 1630 the post of Lord Lyon King at Arms, the senior heraldic office in Scotland. ${ }^{37}$ His Annales form a continuous history of Scotland from 1057 to 1640 while a number of shorter 'memorials of state' cover major events of the period between 1640 and Balfour's death in $1658 .{ }^{38}$ Although written by an antiquarian of considerable repute, the Annales is hardly a work of scrupulous, let alone critical, scholarship. Nonetheless, despite its

${ }^{37}$ For biographical details, see A. du Toit, 'Balfour, Sir James, of Denmiln and Kinnaird, 1600$1657^{\prime}$, ODNB [accessed 16 June 2014].

${ }^{38}$ The Historical Works of Sir James Balfour, ed. J. Haig, 4 vols (Edinburgh, 1824). The Annales comprise the first 2 volumes, from 1057 to 1603 (vol. I) and from 1603 to 1640 (vol. II). Balfour's use of 'u', 'w', 'v', etc has been standardised according to modern conventions, middle Scots 'yogh' rendered as 'y', and 'qu' as 'w'. 
annalistic format and often laconic tone, it becomes increasingly apparent that Balfour's understanding of Scottish political culture, founded on the role of the aristocracy as the king's born counsellors, was generated from within the same ideological milieu as the writings of Hume and Drummond.

This is evident, for example, in his handling of the rebellion against James III in 1482 which, in Balfour's account, follows the now familiar pattern of a phalanx of the 'nobilitey and barons', alarmed at the king's reliance on personal favourites who pandered to his vices, confronting the king at Lauder:

... and ther upbraide him to his face, for hes misgouerment of the realme; for his conteming his nobilitey, and giving care to sicophants and parasits of basse conditione; ... that he had addicted himselve totally to the counsel of Thomas Cochrane, William Rodger, and James Hommile, musrooms sprung upe out of the drege of the commons, whom he had raised to overtope his nobility, misgoverne the countrey, and foster him in his lusts, ryotts and wicked courses. ${ }^{39}$

The king's low-born favourites are duly and justly hanged. However, it is not long before the king betakes himself again to 'a privat miserable lyffe, unworthey of a King, and by all possible meins gives himselve over to be counseled by fellows of basse conditione' ${ }^{40}$ The result is the further rebellion of 1488 and the death of the king following his defeat at Sauchieburn. If Balfour echoes Hume in his indignation at James III's neglect of his born counsellors, and the favour he

\footnotetext{
${ }^{39}$ Balfour, Works, I, 205-6.

${ }^{40}$ Balfour, Works, I, 212.
} 
shows to upstart 'mushrooms', he is much more like Drummond in his ambivalence towards regicide. Thus he carefully notes that the king's son and heir, drafted in by the nobility to lead the rebellion, 'commandit that non should put violent hand one the King his father; yet was he inhumanly killed by some treacherous villanes, his enimies, in bannockburne mill, wher he had fled for shelter'. ${ }^{41}$ Balfour does not explicitly condemn the nobility's resistance, but neither does he openly condone it. Nonetheless, it is with evident approval that he notes that in 1491 James IV made 'choisse of a select number of the nobility and gentrey to be of his privey counsaill, and did solemley promise to do nothing in the governiment without ther counsel and advisse'. ${ }^{42}$

In contrast to Hume and Drummond, Balfour often indicates that parliament is the appropriate forum for discussion of political grievances (with the general assembly as a parallel forum for church affairs). ${ }^{43}$ Yet he is still prone to elide any jurisdictional distinction between these and other conciliar bodies - such as the privy council and conventions of the nobility - in a way that subordinates the institutions themselves to the role of the nobility acting through them. Thus for Balfour, as for Hume and Drummond, it is still the nobility who are duty bound to advise the king - and, in his view, to take action against those whose malign influence over a monarch threatens the commonweal of the realm. A case in point is Balfour's account of the rise and fall of James Stewart, earl of Arran, whose undue influence over James VI led to the

\footnotetext{
${ }^{41}$ Balfour, Works, I, 212-14.

${ }^{42}$ Balfour, Works, I, 217-18.

${ }^{43}$ Balfour frequently mentions parliamentary meetings, sometimes giving details of legislation passed, suggesting that a key source in compiling the Annales was the printed editions of parliamentary statutes from the reign of James I onwards that were published periodically after
} 1566. 
aristocratic coup of 1585 in which Hume and his patron, Angus, had been personally involved. According to Balfour, the rebel lords obliged the king to summon a parliament in which their previous forfeitures were repealed:

This was done at the humble suit of almost the wholl estaites of the realme, a purpose to separate the King from the ambitious and lewd minion, the Earle of Arran, and his ladey, a lascivious wiccked woman, and one blunderd of witchcrafte, and had made the King to neglect and vilipend his nobility; for he so wholly possessed the King, that nothing was done in courte bot by him and his ladey; wich did highly exasperate the nobilitey, to see the King possesit by two such musroomes, that had arisen bot yesterday almost from the earthe, who sought only ther awen preferment, and that with the ruine of the comonwealthe. ${ }^{44}$ While Balfour's metaphoric 'mushrooms' may be new, as is Arran's wicked wife, the basic scenario is familiar enough: the rise of self-seeking upstarts, the usurpation of the traditional functions of the ancient nobility, their alienation from the king and, finally, their public-spirited intervention to restore the traditional political order under a suitably chastened, but also now suitably counselled, monarch. Balfour does not emulate Hume in parsing the distinction between resisting the king and restraining his evil counsellors, but it is a distinction that is effectively elided when he comes to recount events closer to his own time.

Although an office-holder in Charles I's Scottish government, and less than fully committed to a Presbyterian ecclesiastical polity, Balfour was nonetheless increasingly out of

\footnotetext{
${ }^{44}$ Balfour, Works, I, 383.
} 
sympathy with the religious policy pursued by his royal master and the malign influence that he believed the bishops were exercising over him. Indeed, the episcopal bench bore direct comparison with the upstart favourites who had corrupted earlier Stuart monarchs: 'thir unhappy bischopes', he wrote, 'they were eivill counsellers, but worse musitians; for they tempered ther stringes to such a cleiffe [clef] of ambition and superstitious foolriy, that befor ever they yeildit aney sound, they burst all in pieces'. ${ }^{45}$ Like the self-seeking 'mushrooms' who had sought to control James III and James VI, the bishops under Charles I sought 'to advance themselves to over-reule both church and staite, contrary to the laws of God and this natione'. ${ }^{46}$ They had usurped the functions of the nobility, monopolised the ear of the king and were imposing policies and religious practices on the Scots that were bound to alienate them from their prince. Of Charles's 'coronation' parliament of 1633, Balfour wrote:

$\ldots$ of 31 actes and statutes concludit in this parliament, not thre of them bot wer most hurtefull to the liberty of the subiecte; and as it wer als maney partitions to separate the King from his people. This parliament was led one by the Episcopall and court faction, which therafter proved to be that stone that afterwards crusht them in pieces, and the fewell of that flame which sett all Brittane a fyre not long therafter. ${ }^{47}$

As with Drummond, Balfour's anger and disillusionment were perhaps reinforced by the key role he had himself played in choreographing the king's coronation ceremony just days before the

\footnotetext{
${ }^{45}$ Balfour, Works, II, 140.

${ }^{46}$ Balfour, Works, II, 262.

${ }^{47}$ Balfour, Works, II, 200.
} 
parliament met. Certainly he expressed outrage at the king's practice of noting 'with his awen hand' the names of those who voted against his proposals: 'this unseimly acte of his Maiesties bred a grate hearte burning in maney, against his Maiesties proceidingis and governiment' ${ }^{48}$ Similarly, the trial and imprisonment of Lord Balmerino that had moved Drummond to write his highly critical 'Apologetical Letter' was seen by Balfour as an affront to law and justice that was only made possible 'by the over-reuling power of the bischops, and ther wicked and corrupte courte adherents'.49

As Lord Lyon King at Arms, Balfour had a particular professional interest in noble titles and lineages and, like many contemporaries of his social rank, also took a keen interest in chorographical studies and the powerful associations of local families with the landscapes they owned and inhabited. ${ }^{50}$ Not surprisingly, therefore, he was profoundly concerned with Charles I's Act of Revocation of 1625 and the threat this posed to Scottish landholding and thus to the very fabric of noble society. Whatever Charles intended by the Act, its dubious legality and sweeping terms - enabling him to revoke all crown grants of land since before the Reformation of 1560 - was greeted with widespread suspicion and alarm. For Balfour, indeed, it 'was the ground stone of all the mischieffe that followed after, bothe to this kings governiment and family; and whoever were the contrivers of it deserve they and all ther posterity to be reputed by

${ }^{48}$ Balfour, Works, II, 200.

${ }^{49}$ Balfour, Works, II, 216.

${ }^{50}$ An interest shared by Drummond: see R. A. Mason, 'From Buchanan to Blaeu: The Politics of Scottish Chorography, 1582-1654', in Erskine and Mason (eds), Buchanan, pp. 13-47, esp. pp. 39-40. 
thir thre kingdoms, infamous and accursed forever'. ${ }^{51}$ Although Balfour is reticent about who precisely the contrivers of the Act of Revocation were, as his narrative progresses, he points the finger for all the kingdom's ills at the bishops in general and Archbishop John Spottiswoode in particular. To Balfour, in heeding his upstart counsellors, Charles was open to all the charges of vicious misgovernment that had plagued his predecessors. The Act of Revocation, heavy taxation, the manipulation of the Court of Session, the establishment of a new Commission for Grievances - 'nothing els bot the star chamber courte of England under ane other name, come doune heir to play the tyrant, with a specious visor one its face ${ }^{52}$ - were not the actions of a wise and loving prince working in conjunction with a virtuous nobility to preserve and promote the commonweal. On the contrary, they were the acts of a willful king in thrall to evil advisers who were threatening the stability of both kirk and kingdom.

Although Balfour did not theorise about the right of resistance in the way that Hume had done, he left his readers in no doubt of his support for those who resisted the imposition of the Prayer Book in 1637 and went on to draw up the National Covenant in 1638. Balfour clearly had no more liking for the new service book ('Laud's Liturgy') than he did for the bishops who colluded in its introduction - and even less for the 'courte creame and smoothe flourishes' with which 'the Lordes of his Maiesties privey counsaill heir' tried to placate the opposition. ${ }^{53}$ Similarly, although it is not clear whether he himself signed the National Covenant, he evidently approved wholeheartedly of those who refused to sign the rival King's Covenant 'in respect that

\footnotetext{
${ }^{51}$ Balfour, Works, II, 128.

${ }^{52}$ Balfour, Works, II, 131.

${ }^{53}$ Balfour, Works, II, 288.
} 
Episcopacie, abiured by the first Covenant, might subsist by that of the Kinges' ${ }^{54}$ In terms reminiscent of Hume's belief in the nobility's duty to 'resolutely remonstrate their right', Balfour wrote of the Scots' defiant stance in 1638:

... the noblemen, counselors and uthers weill disposed about his Maiesty, loving the peace and tranquility of the countrey, did in verey plaine tearmes shew his Maiesty, that most of his Subjects demands wer reasonable and just; and that it was best to heire and remeed ther grivances in the ordinary way; that is, churche matters in a nationall assembley, and matters of the commonwealthe in a parliament, wher matters being thus trayed, the trew authors of all those eivells will be found out and censured, and the eivells repressed and removed. ${ }^{55}$

Evidently, in Balfour's view, such a procedure was standard practice, legitimised by history and experience. Nor, at least initially, did he betray any of the fear of political disorder and social anarchy that characterises Drummond's response to the train of events that culminated in open rebellion against the king. Balfour did not construe the Covenanters' resistance to Charles I as a threat to monarchy itself. Commenting on what he obviously considered the hysterical reports on the proceedings of the 1639 Parliament and General Assembly sent to London by the earl of Traquair, the king's lord high treasurer in Scotland, he wrote that Traquair 'exeggeratts all the

\footnotetext{
${ }^{54}$ Balfour, Works, II, 294. On the King's Covenant - drawn up in 1639 as a royalist counter to the National Covenant of the previous year - see D. Stevenson, The Scottish Revolution, 16371644, 2nd edn (Edinburgh, John Donald, 2003), pp. 109-12.

${ }^{55}$ Balfour, Works, II, 262.
} 
covenanters deportment and actinges, as tending to the destruction of the fundamentall laws of the kingdome, and overthrow of monarchical governiment; and makes evrey molehill a montane'.56

Crucially, however, by the following year Balfour had completely changed his mind and was gripped with deep unease at the constitutional revolution initiated by the parliament of June 1640. In his view the sweeping changes - from the abolition of the clerical estate to the introduction of a Triennial Act to the subjection of the Committee of the Articles to the will of parliament - amounted to the 'grattest change at one blow that euer hapned to this churche and staite these 600 yeires bypast'. Parliament had imposed constitutional restraints on the king that went well beyond anything that Balfour had envisaged: 'for in effecte it overturned not onlie the ancient state government, bot fettered monarchie with chynes and sett new limits and marckes to the same, beyond wich it was not legally to proceid'. ${ }^{57}$ What for Balfour had begun as a legitimate protest against a monarch misled by evil counsel had turned into an assault on monarchy itself. A parliament that functioned without the king's authority - that effectively stripped the king of authority - represented a radicalisation of the Covenanting movement that Balfour had not anticipated and could not countenance. It was with a heavy heart that he chose to end volume 2 of his Annales in 1640, lamenting that the fundamentals of government in both church and state had been 'verey muche altered, if not overturned from what they wer, both in his [the king's] fathers tyme, and in his awen till that yeire'. He had resolved, he went on in terms that graphically highlight the revolutionary nature of what he was witnessing, 'to begin

\footnotetext{
${ }^{56}$ Balfour, Works, II, 363. For a fuller and more sympathetic account of Traquair's actions in 1639, see Donald, An Uncounselled King, pp. 201-17.

${ }^{57}$ Balfour, Works, II, 379.
} 
with that yeire [1641] in ane other volume, becausse I must speake in ane other language, and in other tearmes now then I did formerly, befor the raines of governiment wer slacked, and the bodey did begin to call itselve the estaites, without any mentione of him who was the headpoliticke of that bodey'. 58

\section{IV}

There is a powerful sense of nostalgia in Balfour's closing sentences, not only falling back on the metaphor of an organic body politic much favoured by James VI and I, but also invoking an earlier 'golden age' associated with the late king's reign. But this was surveying the past through rose-tinted spectacles. One of the leaders of the Covenanters, a scion of the ancient Scottish nobility, John Leslie, sixth earl of Rothes (c.1600-41), wrote on Charles I's accession in 1625 of the 'impairing of the libertys of the Nobility in both Counsell and Parliament' under his father and of his high hopes that the new king would restore them. ${ }^{59}$ Such hopes were dashed and Rothes, a committed Presbyterian, became one of the leaders of the Covenanters. Yet he was also a courtier who, on his death in 1641, and much to the dismay of the more radical of his Covenanting peers, was actively engaged in negotiations with Charles I over patronage for himself and a peaceable settlement for his kirk and kingdom. Perhaps for Rothes as for Balfour, the king's evil counsellors - those ‘unhappy' bishops - were a means of sidestepping a more

\footnotetext{
${ }^{58}$ Balfour, Works, II, 429.

${ }^{59}$ Correspondence of Sir Robert Kerr, First Earl of Ancram, and his Son, William, Third Earl of Lothian, ed. D. Laing, 2 vols (Edinburgh, Bannatyne Club, 1875), I, 35-8. I owe this reference to Dr Alan MacDonald. On Rothes's letter see further MacDonald's essay in this volume.
} 
profound ideological confrontation. With the bishops gone, however, the fiction of loyalty to the king but opposition to his policies became impossible to maintain. As David Stevenson pointed out many years ago, the 'Letter on Sovereign Power', long attributed to the marquess of Montrose, but actually written by his brother-in-law, Archibald Napier, Lord Merchiston, is evidence of the emergence in 1641 of a much more polarised ideological landscape in which the nature of sovereignty was being actively debated among the ranks of the leading lay Covenanters. ${ }^{60}$ Napier drew heavily on Bodin to support the case for strict obedience, conceding only - in terms similar to Drummond - that the king's power was strongest and most durable when exercised moderately and within the limits set 'by the laws of God, of Nature, and the fundamental laws of the country' ${ }^{61}$ While Montrose rejected Napier's views, it was becoming increasingly clear that the kind of baronial conciliarism espoused by Balfour - based on mutual trust between crown and nobility - would no longer meet the needs of the polity (if it ever had). The limits of the discourse of counsel - the lack of any clear remedy when confronted by a king who rejected 'good' counsel - were being exposed as never before. The belated publication of Hume's History in 1644 perhaps indicates a recognition of the need to reinforce the idea of the nobility's role as the king's born counsellors with a more explicit defence of their right to resist. But the publication of Samuel Rutherford's Lex, Rex in the same year signalled the extent to which the Covenanters had moved beyond the baronial conciliarism discussed here to a harder edged and much more radical constitutionalism grounded in a potent mix of scripture, neo-

${ }^{60}$ D. Stevenson, 'The "Letter on Sovereign Power" and the Influence of Jean Bodin on Political Thought in Scotland', Scottish Historical Review, 61 (1982), 25-43.

${ }^{61}$ For the text of the 'Letter', see J. Buchan, Montrose (London, Nelson \& Sons, 1928), pp. 397406 (qu. p. 400). 
scholastic philosophy and legal precedent. ${ }^{62}$

${ }^{62}$ See J. Coffey, Politics, Religion and the British Revolutions: The Mind of Samuel Rutherford (Cambridge, Cambridge University Press, 1997). 